\title{
Operationalized indicators: Integrating community health worker and client views to assess community health systems
}

Frontline Health Project

Follow this and additional works at: https://knowledgecommons.popcouncil.org/departments_sbsr-rh How does access to this work benefit you? Let us know!

\section{Recommended Citation}

Frontline Health Project. 2021. "Operationalized indicators: Integrating community health worker and client views to assess community health systems," Frontline Health Indicators Guide. Washington, DC: Population Council. 


\section{Operationalized Indicators: Integrating Community Health Worker and Client Views to Assess Community Health Systems}

\section{BACKGROUND}

Community Health Workers (CHWs) are on the front lines of improving health outcomes and health equity in communities worldwide - providing health education, delivering basic health services, and supporting linkages to facilities across a range of health areas [1,2]. There is growing commitment to strengthening and scaling up $\mathrm{CHW}$ programs to achieve universal health coverage (UHC) in low and middle-income countries (LMICs). With this effort comes the need to effectively measure $\mathrm{CHW}$ program performance [3].

Systems to measure CHW program performance in a country should incorporate data from multiple sources, employ well-validated and theoretically grounded measures/indicators, and be practical to implement [4]. In addition, it is important to move towards a harmonized measurement system to assess community health $(\mathrm{CH})$ system performance worldwide, while also recognizing that metrics and data sources chosen in any one country depend on $\mathrm{CH}$ system maturity, funding, systems readiness for data collection mechanisms, and contextual realities.

It is critical to integrate CHW and community members' perspectives within efforts to assess community health workforce performance. Hearing from $\mathrm{CHWs}$ and their

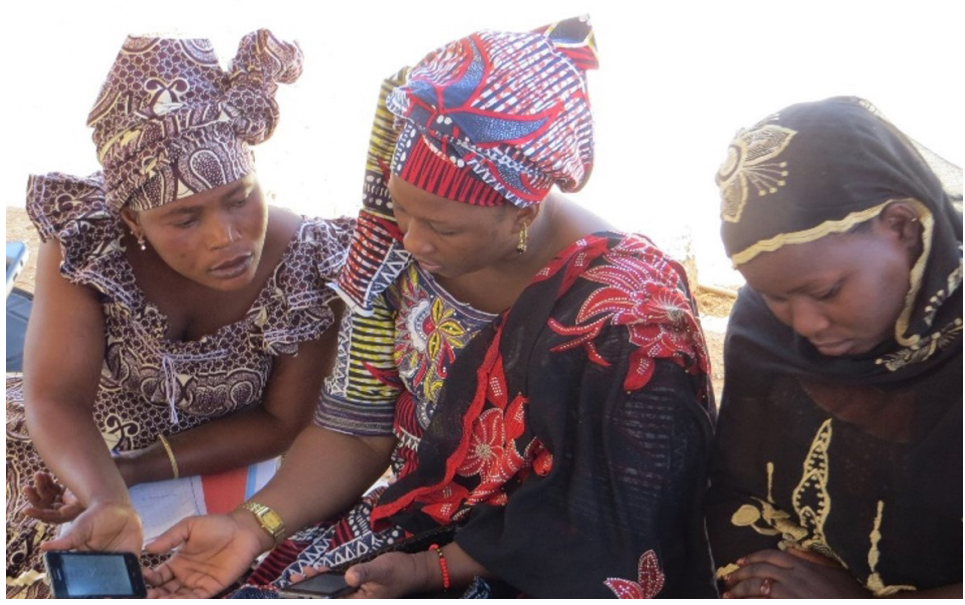

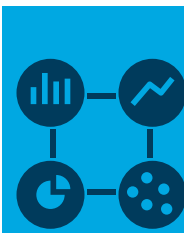

FRONTLINE HEALTH: HARMONIZING METRICS, ADVANCING EVIDENCE, ACCELERATING POLICY

In collaboration with USAID and UNICEF and with funding from the Bill \& Melinda Gates Foundation, the Frontline Health project is a three-year joint research, policy, and advocacy endeavor of the Population Council and Last Mile Health. The project developed and operationalized a core set of measures for $\mathrm{CHW}$ performance in select countries from the Integrating Community Health partnership (ICH), and supports the national and global adoption of these metrics for routine monitoring [10].

clients can complement and enrich understanding gained from other data sources such as program/ service monitoring data, coverage assessments, patient registers, CHW logs, and health management information systems (HMIS) [5-8]. In particular, capturing $\mathrm{CHW} /$ community perceptions can help identify specific under-performing areas of $\mathrm{CHW}$ programming, as well as track progress over time - it may also help distinguish between relevant subgroups to promote equitable support to $\mathrm{CHWs}$ and $\mathrm{CH}$ systems.

While these data sources are often collected on a routine and relatively frequent basis since they involve collating data from records/databases, there is also growing interest in rapid, routine methods of surveying $\mathrm{CHWs}$ and/or clients/community members, such as via community scorecards [9]. In addition, while necessarily implemented less frequently, periodically implementing more comprehensive surveys with $\mathrm{CHWs}$ and clients/community members, and 


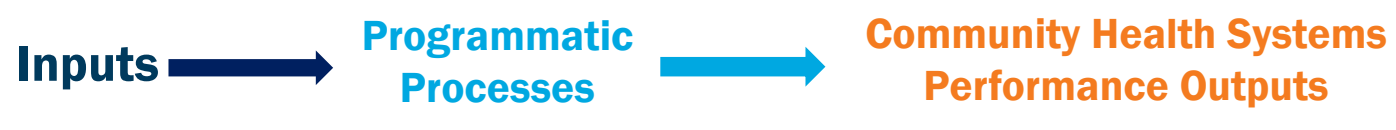

\section{Outcomes}

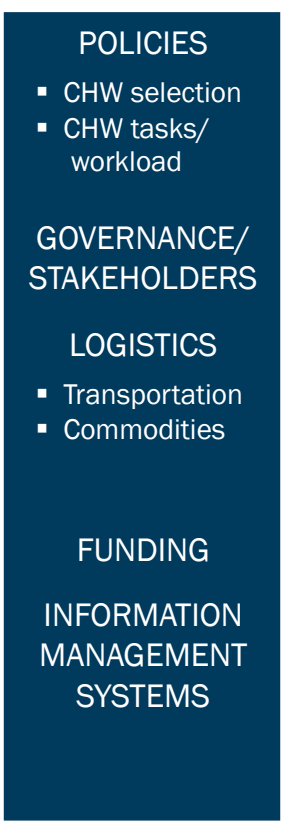

\begin{tabular}{|c|c|}
\hline SUPPORTIVE & CHW-Level Outputs \\
\hline $\begin{array}{l}\quad \text { SYSTEMS } \\
\text { - Supervision \& } \\
\text { performance } \\
\text { appraisal } \\
\text { - Data use }\end{array}$ & $\begin{array}{l}\text { CHW } \\
\text { COMPETENCY } \\
\text { - } \text { CHW } \\
\text { knowledge } \\
\text { - Service delivery }\end{array}$ \\
\hline $\begin{array}{c}\text { CHW } \\
\text { DEVELOPMENT } \\
\text { - Recruitment }\end{array}$ & $\begin{array}{l}\text { - Data reporting } \\
\text { - Absenteeism }\end{array}$ \\
\hline $\begin{array}{l}\text { - Training } \\
\text { - Incentives }\end{array}$ & $\begin{array}{c}\text { CHW } \\
\text { WELL-BEING }\end{array}$ \\
\hline $\begin{array}{l}\text { SUPPORT FROM } \\
\text { COMMUNITY- } \\
\text { BASED GROUPS }\end{array}$ & $\begin{array}{l}\text { - Job satisfaction } \\
\text { - Attrition/ } \\
\text { retention }\end{array}$ \\
\hline
\end{tabular}
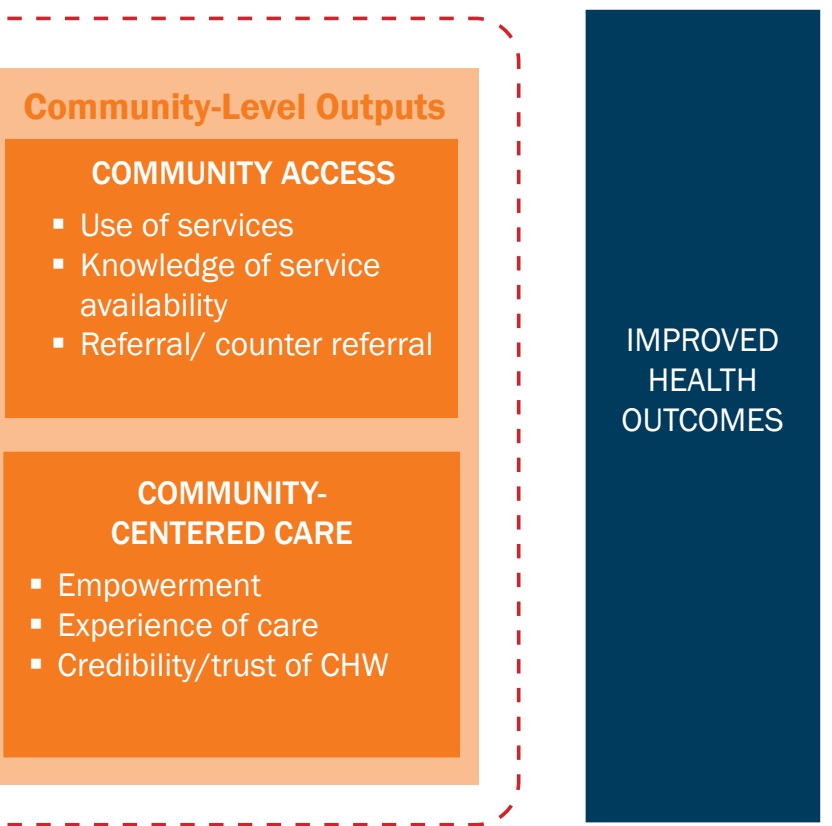

Economic Evaluation

\section{Equity, Gender, Accountability}

meaningfully integrating their perspectives with other data sources, can provide more comprehensive information for how to strengthen and scale CHW programs.

We also highlight 20 of the 30 indicators (including at least one from each domain) that we believe would be well suited for routine/rapid data collection methodologies and/ or integration within $\mathrm{CH}$ service provision assessments (SPAs), demographic health surveys (DHS) or other population-based surveys.

This measurement guide proposes 30 indicators (comprising 91 total questions, including several multiitem scales) that can be collected in surveys with $\mathrm{CHWs}$ (19 indicators) and community members (11 indicators).

The comprehensive set of 30 indicators aims to robustly capture seven critical domains of CHW performance:

- Supportive Systems

- CHW Development

- Support from Community Groups,

- CHW Competency

- CHW Wellbeing

- Community Access, and Community Centered Care
These domains come from the Population Council's CHW Performance Measurement Framework (Figure 1) [6] which was developed under the Frontline Health (FLH) project and seeks a balance between comprehensive and pragmatic measurement of $\mathrm{CHW}$ performance within primary health care $(\mathrm{PHC})$ systems [10].

This framework is situated within several donor and international agency-coordinated efforts over the past decade to engage national and global stakeholders in developing frameworks and tools to promote functional, effective, quality, and accountable community health systems [5-8, 11-15].

For interested readers, Figure 2 on page 9 shows these select global guidelines and national strategies, their operationalization in planning and priority setting tools, tracked by progress, output, and outcome measures.

\section{APPROACH TO SELECTING FINAL INDICATORS}

The indicators were tested and validated in surveys with $\mathrm{CHWs}$ and/or community members in Bangladesh, Kenya, Haiti, Mali, and Uganda, which covered several health areas such as family planning, maternal and 
child health, and general PHC services [15], and finalized through consultation with global and national stakeholders. The pool of indicators tested came from 46 total indicators created as part of the Community Health Systems Measurement Framework (Figure 1) [6]. A subset of indicators and scales that elicited $\mathrm{CHW}$ and client/community member perspectives, covering the seven domains noted above, were tested as part of FLH's operational research. These scales, which are described in a separate brief as well as several manuscripts, included the Multi-dimensional Motivation Scale (for CHWs), the Trust in $\mathrm{CHWs}$ Scale (for clients) and the Client Empowerment in Community Health Systems Scale (for clients) [16-19]. These scales are included as three of the 30 recommended indicators.

To select the final set of recommended indicators, we followed an iterative process that included consultation among multi-country team members with deep knowledge of their community health systems contexts. Specifically, we:

- Reviewed all survey datasets from FLH studies in Bangladesh, Kenya, Haiti, Mali, and Uganda (Table 1) to extract potential indicators from relevant framework domains.

- Examined descriptive statistics for each indicator (frequencies/means and variances), and associations with other relevant variables when feasible.

Criteria for inclusion in final list of indicators included:

1. Demonstrated adequate variability in a majority of countries (e.g., $>10 \%$ or $<90 \%$ for a binary indicator) OR demonstrate variability between countries (e.g., $>10 \%$ difference)

2. Salience within a specific $\mathrm{CH}$ system and globally based on multi-country team and global stakeholder perspectives

3. Together, indicators within a particular domain comprehensively capture $\mathrm{CHW}$ and community perspectives on that domain.

As described above, the three scales were also selected as indicators. While we recommend using the full scales whenever possible, we also recognize that limited funding may restrict the frequency and ease of information gathering in programmatic settings.
TABLE 1. SURVEY DATA USED TO FINALIZE INDICATORS

\begin{tabular}{|l|c|c|}
\multicolumn{1}{|c}{ Country } & $\begin{array}{c}\text { Surveys with } \\
\text { CHWs (n) }\end{array}$ & $\begin{array}{c}\text { Surveys with } \\
\text { clients/community } \\
\text { members }(n)\end{array}$ \\
\hline Bangladesh & 66 & 1,384 \\
\hline Haiti & -- & 616 \\
\hline Kenya & 211 & 306 \\
\hline Mali & 141 & -- \\
\hline Uganda & 399 & -- \\
\hline
\end{tabular}

Therefore, given the importance of assessing these concepts in routine/rapid data collection methodologies and/or as part of the DHS and other routine surveys, we have also included a short scale or specific items that reflect each scale's subdomains. (For example, the item "Does the CHW always treat you with respect? (Yes/No)" can be seen as a brief representation of the "Respectful communication" subscale of the Trust in CHWs scale.)

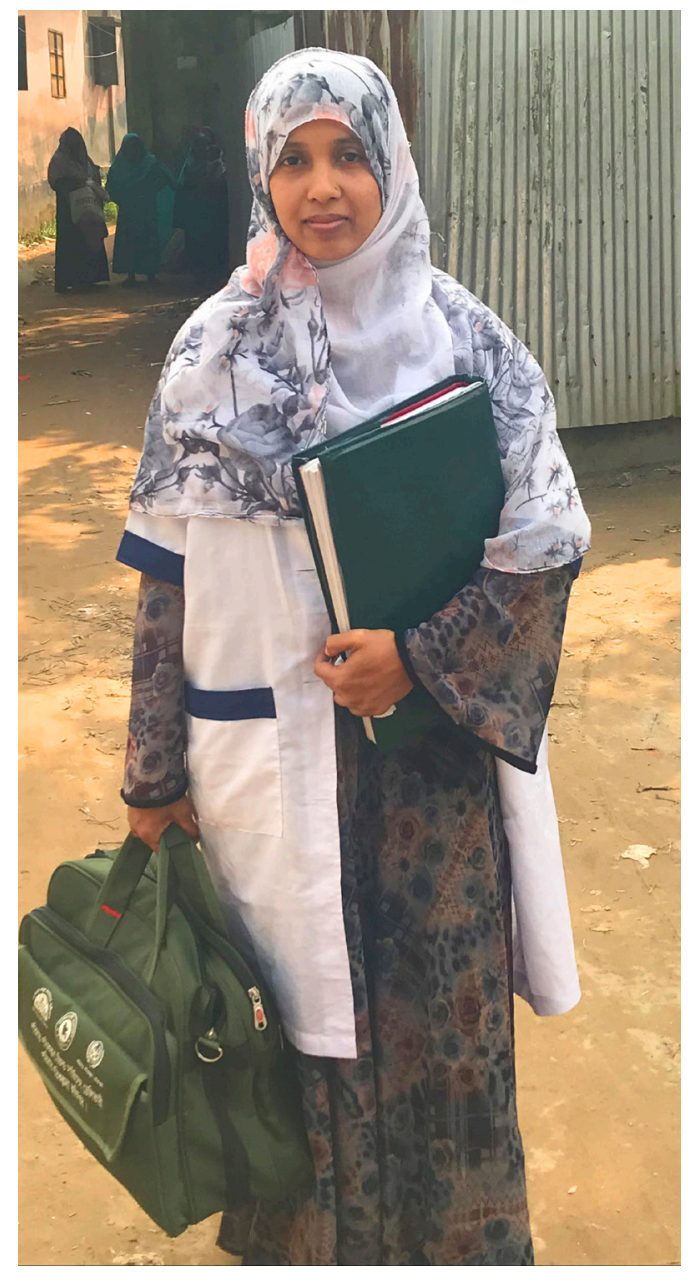

Photo credit: Pooja Sripad. 


\section{TABLE 2. RECOMMENDED INDICATORS FOR ASSESSING COMMUNITY HEALTH SYSTEMS}

Table 2 below describes indicators for assessing the performance of CHW programs. Indicators that may be well-suited for use in routine/short surveys to "take the temperature" of CHW program performance are marked with an icon (see Key)

\section{PROGRAMMATIC PROCESSES}

Indicator

\begin{tabular}{|c|c|}
\hline & Supportive Systems \\
\hline
\end{tabular}

1. \% of $\mathrm{CHWs}$ supervised in the last 3 months

2. \% of CHWs satisfied with support received from supervisor

3. \% of $\mathrm{CHWs}$ satisfied with feedback received from their supervisor

4. \% of CHWs satisfied with availability of drugs, supplies, equipment

5. \% of CHWs satisfied with community members' ability to contribute to improving health services

6. \% of CHWs satisfied with support from leaders and stakeholders

7. \% of $\mathrm{CHWs}$ satisfied with decision-making processes

your work"
your work"

\section{Support from Community Groups}

How satisfied are you with:
services?" stakeholders for CHWs' work?"

\begin{tabular}{|l|l|}
\hline $\begin{array}{l}\text { "Have you met with your supervisor in the last } 3 \\
\text { months?" }\end{array}$ & Yes/No \\
\hline How satisfied are you with: &
\end{tabular}

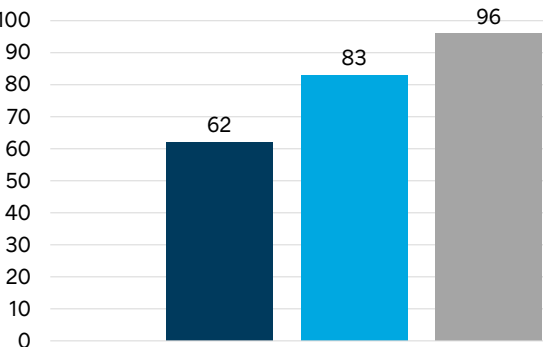

$\%$ of $\mathrm{CHWs}$ reporting supervision visit in last three months - Bangladesh $\backsim$ Kenya $\llbracket$ Mali

Availability of drugs, supplies, and equipment for your work

"Feedback your supervisor provides on areas that you can improve on"

"Availability of drugs, supplies and equipment for

"Opportunities for community members to contribute their ideas to improve health

"Support from community health leaders and

"Decision-making processes used by community dissatisfied; satisfied; very satisfied
Very dissatisfied; dissatisfied; satisfied; very satisfied (ror
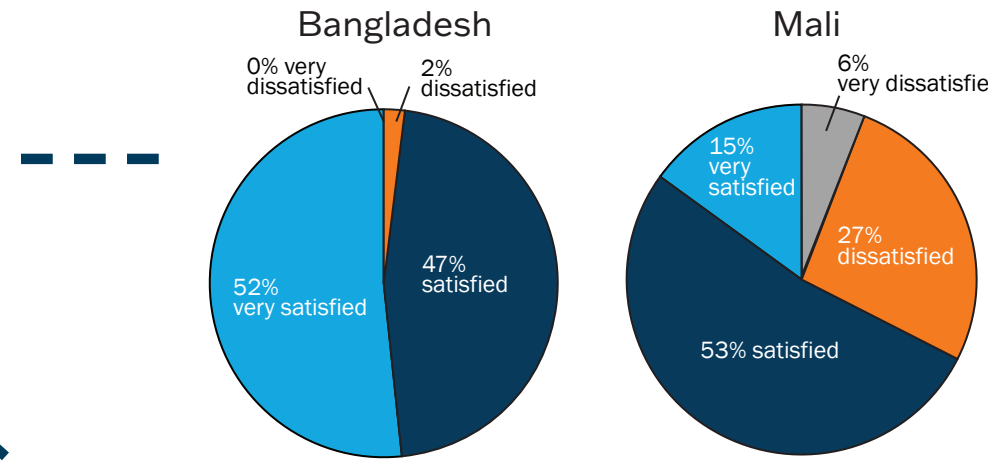


\begin{tabular}{|c|c|c|}
\hline \multicolumn{3}{|c|}{ COMMUNITY HEALTH SYSTEM PERFORMANCE OUTPUTS } \\
\hline Indicator & Question / Item wording & Response Options \\
\hline \multicolumn{3}{|c|}{ CHW Wellbeing } \\
\hline $\begin{array}{l}\text { 8. \% of } \mathrm{CHWs} \text { motivated in } \\
\text { their work }\end{array}$ & "Overall, I am motivated to work here." & \multirow{6}{*}{$\begin{array}{l}\text { Strongly disagree (1); } \\
\text { disagree (2); agree (3); } \\
\text { strongly agree (4). Generate } \\
\text { mean scores by taking the } \\
\text { mean of non-missing items } \\
\text { for a final range of } 1.0 \text { to } 4.0 .\end{array}$} \\
\hline $\begin{array}{l}\text { 9. \% of CHWs at risk of } \\
\text { attrition }\end{array}$ & "I frequently think of quitting this job." & \\
\hline $\begin{array}{l}\text { 10. } \% \text { of } \mathrm{CHWs} \text { well- } \\
\text { supervised }\end{array}$ & "I am supervised well." & \\
\hline $\begin{array}{l}\text { 11. \% of CHWs who feel } \\
\text { valued and capacitated in } \\
\text { work* }^{*}\end{array}$ & "I feel valued and capacitated in my work." & \\
\hline $\begin{array}{l}\text { 12. \% of } \mathrm{CHWs} \text { respected } \\
\text { and supported by peers* }\end{array}$ & $\begin{array}{l}\text { "I am respected and supported by my } \\
\text { peers at work." }\end{array}$ & \\
\hline $\begin{array}{l}\text { 13. \% of CHWs who feel well- } \\
\text { compensated for work* }\end{array}$ & $\begin{array}{l}\text { "I am compensated well in relation to my } \\
\text { workload." }\end{array}$ & \\
\hline $\begin{array}{l}\text { 14. Average score on Multi- } \\
\text { dimensional Motivation } \\
\text { (MM) Scale (22 items) } \\
\text { See: Reference } 16 \text { - } 17\end{array}$ & $\begin{array}{l}22 \text { items covering four domains: } \\
\text { Quality of supervision (example item: } \\
\text { "Support your direct supervisor gives you } \\
\text { in your work") } \\
\text { Feeling valued and capacitated in your } \\
\text { work (example items: "Respect received } \\
\text { from community for doing this work"; } \\
\text { "Availability of drugs, supplies, and } \\
\text { equipment for your work") } \\
\text { Peer respect and support (example item: } \\
\text { "Cooperation among CHWs") } \\
\text { Compensation and workload (example } \\
\text { item: "Amount of total financial incentives } \\
\text { you receive") }\end{array}$ & $\begin{array}{l}\text { Response options for set } \\
\text { of satisfaction items: Very } \\
\text { dissatisfied, dissatisfied, } \\
\text { satisfied, very satisfied } \\
\text { (The score for each domain } \\
\text { is then weighted by how } \\
\text { important each is to the } \\
\text { respondent) }\end{array}$ \\
\hline
\end{tabular}

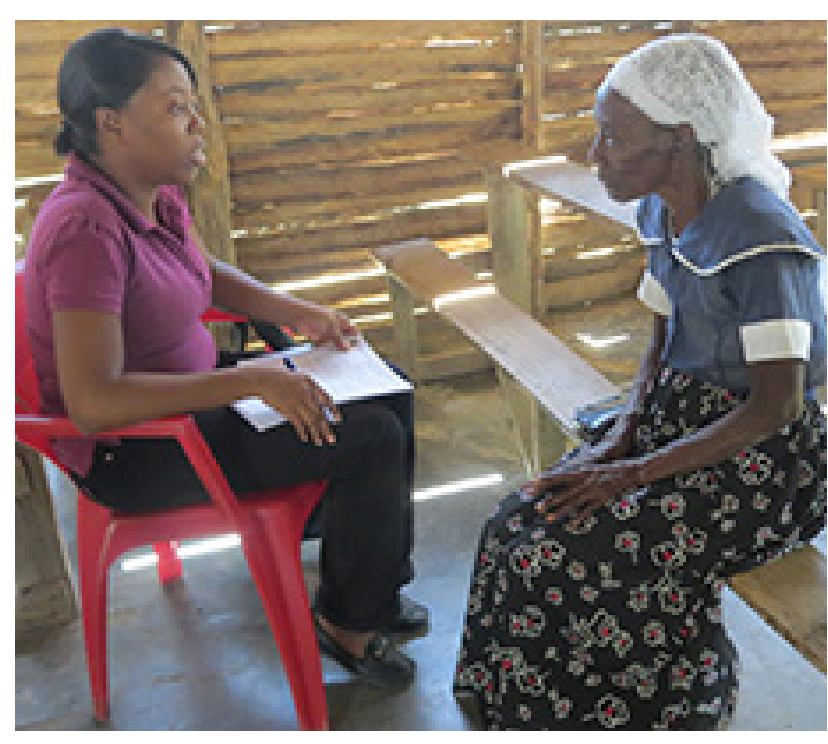

Photo credit: Zanmi Lasante.

The mean score was 14.5 in Bangladesh (on a scale of -24 to +24 ), with peer respect and support the highest-scoring sub-domain.

The mean score was 5.0 in Mali, with quality of supervision the highest-scoring sub-domain.

Compensation was the lowestscoring sub-domain in both countries.

Key: 


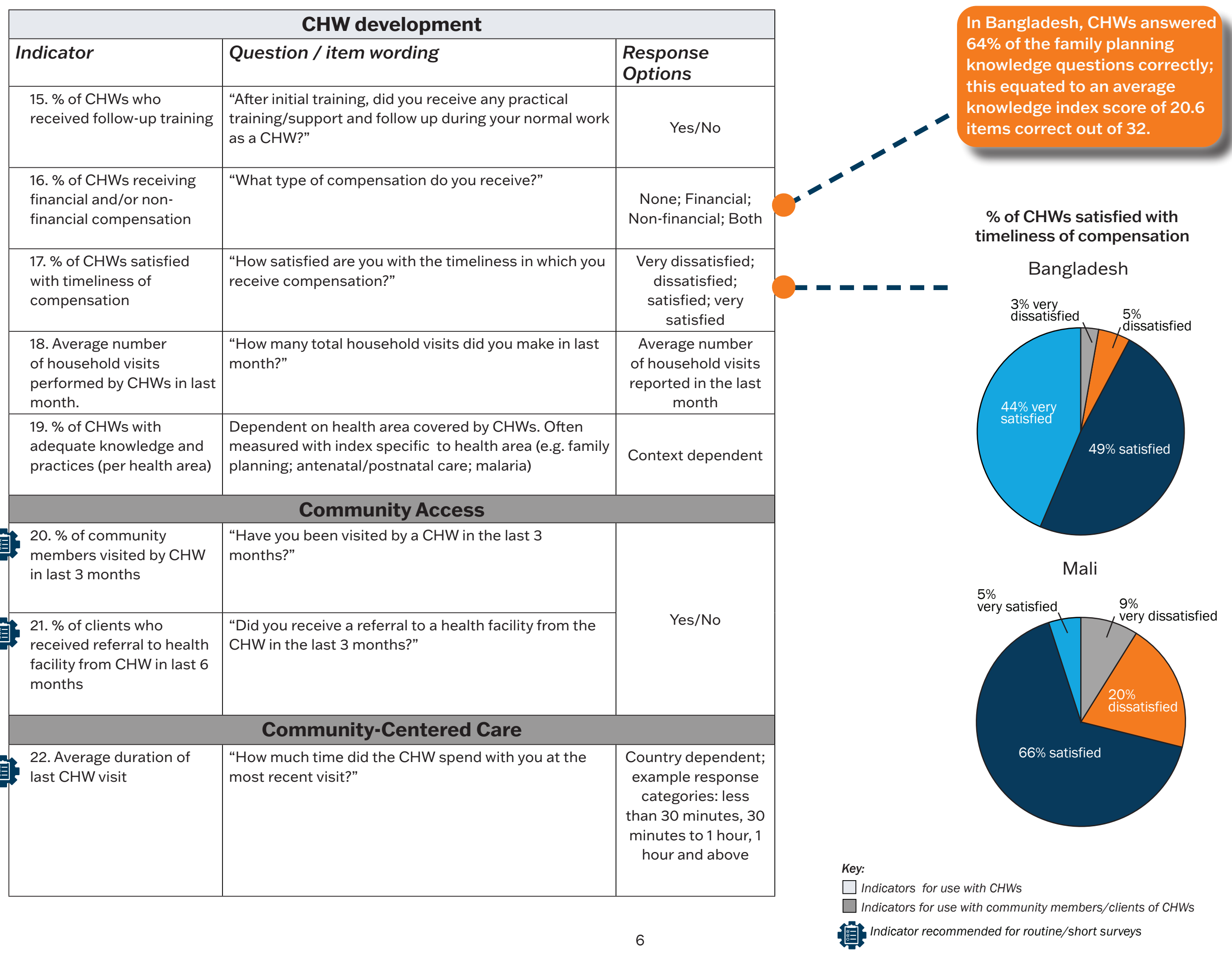


Subdomain of Community-centered care: Experience of care

\begin{tabular}{|c|c|c|}
\hline Indicator & Question / item wording & $\begin{array}{l}\text { Response } \\
\text { Options }\end{array}$ \\
\hline & $\begin{array}{l}\text { Please let me know how much you agree or disagree } \\
\text { with the following statement: }\end{array}$ & \\
\hline $\begin{array}{l}\text { 23. \% of clients } \\
\text { satisfied with } \mathrm{CHW} \\
\text { services }\end{array}$ & $\begin{array}{l}\text { "I was satisfied with the services I received from the } \\
\mathrm{CHW(s)} \mathrm{in} \mathrm{the} \mathrm{last} \mathrm{six} \mathrm{months."}\end{array}$ & \multirow{2}{*}{$\begin{array}{l}\text { Strongly disagree; } \\
\text { disagree; agree; } \\
\text { strongly agree }\end{array}$} \\
\hline $\begin{array}{l}\text { 24. \% of clients who } \\
\text { would recommend } \\
\mathrm{CHWs} \text { to a friend }\end{array}$ & $\begin{array}{l}\text { "I would recommend a friend to the CHW(s) I have } \\
\text { seen in the last six months." }\end{array}$ & \\
\hline
\end{tabular}

\section{Subdomain of Community-centered care: Empowerment}

25. Average score on Influence of CHWs on Empowerment Scale (5 items)

See: Reference 18

26. Average score on Client Empowerment in Community Health Systems Scale (CE-

$\mathrm{CHS})$ (16 items)

See: Reference 18
1. "I can better make decisions about my health and

my children's health because of my interactions with CHWs."

2. "I can better share health information with others because of my interactions with CHWs."

3. "I can better get the care I need from my clinic because of my interactions with $\mathrm{CHWs."}$

4. "I can better improve my clinic and/or the health system because of my interactions with CHWs."

5. "I can better contribute to my community because of my interactions with $\mathrm{CHWs."}$

\section{Sixteen items covering three domains:}

Personal agency around health (example item: "I feel in control of my health")

Agency in sharing health information with others (example item: "I feel confident sharing health information with my family/friends")

Engagement in community health systems (example item: "I can participate in making decisions that improve health in my community")
Strongly disagree (1); disagree (2); agree (3); strongly agree (4). Generate mean scores by taking the mean of non-missing items for a final range of 1.0 to 4.0 .

\section{Client Empowerment in Community Health Systems} Scale (CE-CHS): Average scores

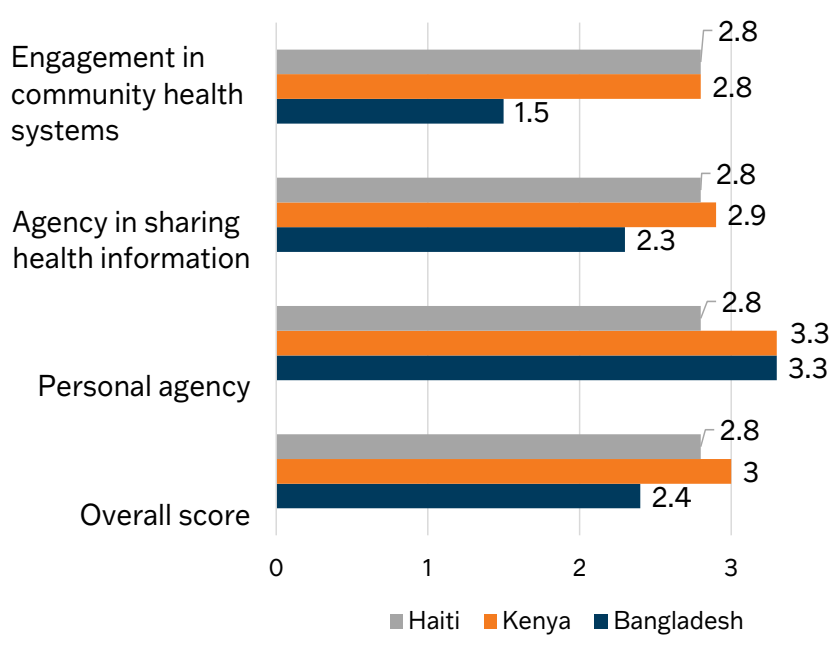

Key:

$\square$ Indicators for use with CHWs

$\square$ Indicators for use with community members/clients of CHWs

Indicator recommended for routine/short surveys 


\begin{tabular}{|c|c|c|}
\hline \multicolumn{3}{|c|}{ Subdomain of Community-Centered Care: Empowerment } \\
\hline Indicator & Question / item wording & $\begin{array}{l}\text { Response } \\
\text { Options }\end{array}$ \\
\hline & $\begin{array}{l}\text { Please let me know how much you agree or disagree } \\
\text { with the following statement: }\end{array}$ & \\
\hline $\begin{array}{l}\text { 27. Average score on Civic } \\
\text { Engagement Scale ( } 7 \text { items) } \\
\text { See: Reference } 18\end{array}$ & $\begin{array}{l}\text { 1. "I like to work on solving a problem in my community } \\
\text { rather than waiting for someone else to address it." } \\
\text { 2. "I understand what's going on in my community." } \\
\text { 3. "I understand the important social issues that affect } \\
\text { my community." } \\
\text { 4. "I understand the important government/policy } \\
\text { issues that affect my community." } \\
\text { 5. "I understand the important environmental issues } \\
\text { that affect my community." } \\
\text { 6. "I can participate in making decisions for my } \\
\text { community." } \\
\text { 7. "There are plenty of ways I can participate in making } \\
\text { decisions for my community." }\end{array}$ & $\begin{array}{l}\text { Strongly disagree } \\
\text { (1); disagree (2); } \\
\text { agree (3); strongly } \\
\text { agree (4). Generate } \\
\text { mean scores by } \\
\text { taking the mean of } \\
\text { non-missing items } \\
\text { for a final range of } \\
1.0 \text { to } 4.0\end{array}$ \\
\hline \multicolumn{3}{|c|}{ Subdomain of Community-Centered Care: Trust } \\
\hline $\begin{array}{l}\text { 28. \% perceiving } \mathrm{CHW} \\
\text { demonstrates healthcare } \\
\text { competence* }^{\text {complat }}\end{array}$ & $\begin{array}{l}\text { "Does the CHW always seem capable of providing the } \\
\text { best care possible?" }\end{array}$ & \multirow{2}{*}{ Yes/No } \\
\hline $\begin{array}{l}\text { 29. \% perceiving } \mathrm{CHW} \\
\text { demonstrates respectful } \\
\text { communication* }\end{array}$ & "Does the CHW always treat you with respect?" & \\
\hline $\begin{array}{l}\text { 30. Average score on Trust in } \\
\text { CHWs Scale (10 items) } \\
\text { See: Reference } 19\end{array}$ & $\begin{array}{l}10 \text { items covering two domains: } \\
\text { Healthcare competence (example item: "How often } \\
\text { have you felt the CHW knew as much as s/he should } \\
\text { about a health topic?") } \\
\text { Respectful communication (example item: "How often } \\
\text { has the CHW been an excellent listener?") }\end{array}$ & $\begin{array}{l}\text { Never (1); Some of } \\
\text { the time (2); Most } \\
\text { of the time (3); } \\
\text { All of the time (4). } \\
\text { Generate mean } \\
\text { scores by taking } \\
\text { the mean of non- } \\
\text { missing items for } \\
\text { a final range of } 1.0 \\
\text { to } 4.0\end{array}$ \\
\hline
\end{tabular}

\section{Trust in CHWs Scale: Average scores}

Respectful communication

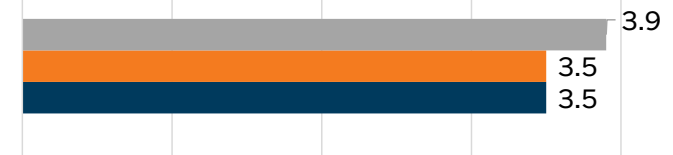

Health care competence

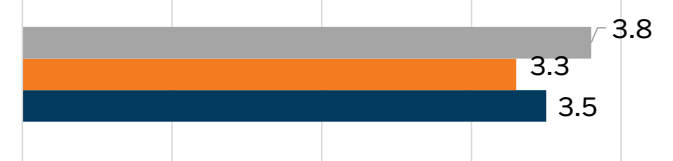

Overall score

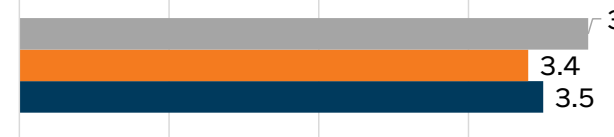

\section{$-3.8$}

- Haiti $\quad$ Kenya $\quad$ Bangladesh

Key:

$\square$ Indicators for use with CHWs

Indicators for use with community members/clients of CHWs Indicator recommended for routine/short surveys 


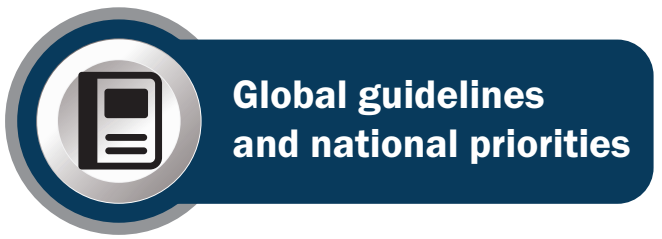

WHO Guideline

on Health Policy

and System Support

to Optimize

Community Health

Worker Programmes

Assists national governments and partners improve the implementation, design, performance, and evaluation of $\mathrm{CHW}$ programs to contribute towards UHC.

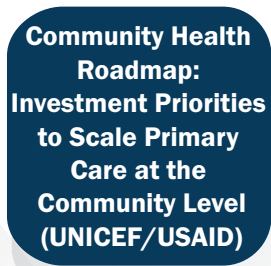

Elevates national health priorities and create a common agenda for investments in community health among 15 countries.
Minimum Quality

Standards and

Indicators for

Community

Engagement (UNICEF)

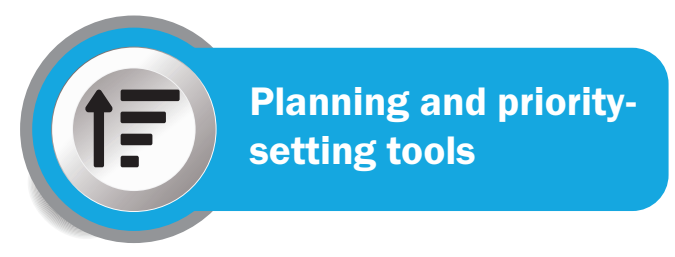

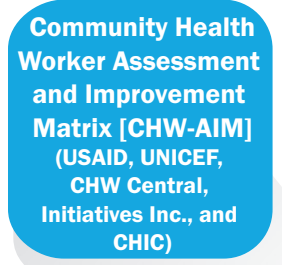

Serves as an assessment tool to design, evaluate, and strengthen $\mathrm{CHW}$ programs and identify implementation gaps in CHW programs.

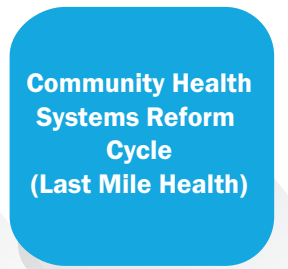

Guides national priorities for community health, designs $\mathrm{CHW}$ scale-up efforts, and diagnoses challenges or gaps in successful scale-up and integration.
Establishes fundamental standards for defining community engagement principles, key actions, goals, and benchmarks.

\section{CHW Coverage and Capacity Tool [C3] (MCSP/USAID)}

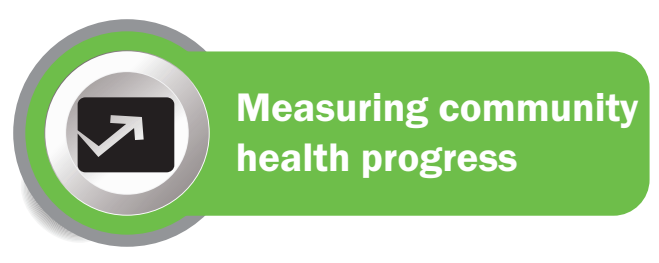

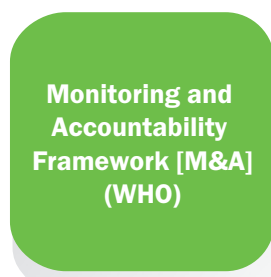

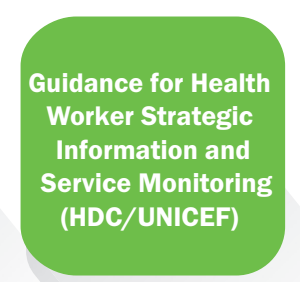

Offers metrics for CHW number/density, strategy, selection and skills, supervision, system support, and supply for stakeholders to inform policy and programmatic decisions.

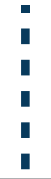

National Health Workforce Accounts ! CHW Registries (HIS).
Offers common indicators that CHWs report at the time they provide services, and aims to align/integrate community data into reporting of health information systems

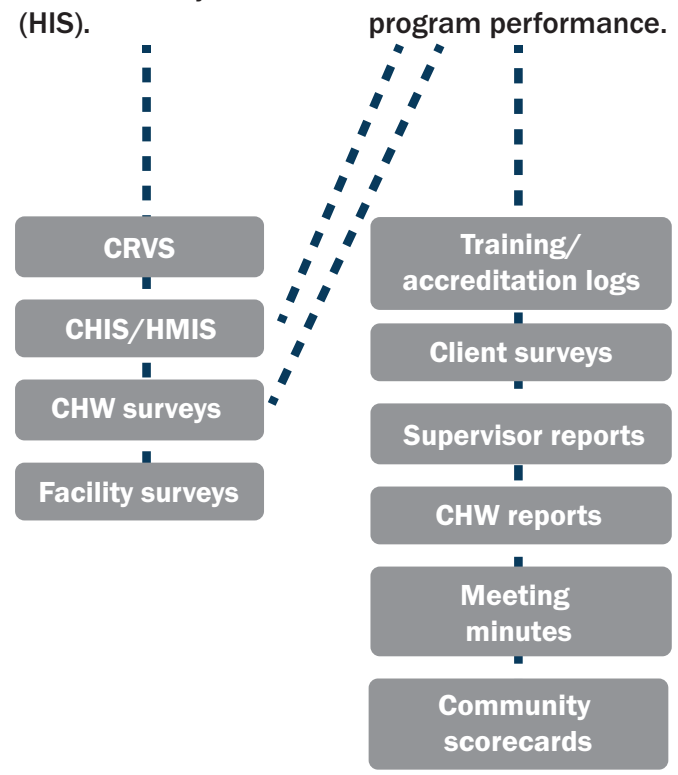

Estimates the number, geographic distribution, and scope of CHWs necessary to achieve nationallyidentified community health targets. 


\section{IMPLEMENTING INDICATORS}

We hope these indicators prove useful to policy makers, program managers, and implementers in meaningfully integrating $\mathrm{CHW}$ and community perspectives when assessing $\mathrm{CH}$ system performance and tracking improvements over time. The intention is to complement the portfolio of existing global measurement tools that inform country community health monitoring and evaluation frameworks, further supporting localized decision-making in community health.

We offer the following recommendations for integrating and applying the indicators, while also recognizing that such recommendations may be revised based on experiences across countries in the coming years.

Consider taking advantage of both the brief and full sets of indicators. The brief set of 20 indicators (13 at $\mathrm{CHW}$ level and 7 at community member/client level) offer a simpler/less expensive option to integrate select items into more rapid/ routine collection and monitoring effort at national and program levels. We encourage collecting information on the longer set of 30 indicators (19 at CHW level, 11 at community member/client level) every 2-3 years to give a more complete picture of a country's CH systems' performance progress, quality, and accountability.

Map out potential modes and timing of data collection - both integrating indicators into existing activities, as well as initiating new processes/ special studies. An example is included in Table 3. If no such opportunities exist, consider advocating for adding them to the national monitoring and evaluation strategy.

Ensure data are collected through a "neutral third party", to avoid bias related to the interviewer and ensure honest participant response. For example, CHWs should be interviewed by someone who is not part of the formal CHW supervision or compensation structure, and community members/clients by someone who is not part of the local $\mathrm{CH}$ system.

TABLE 3. ILLUSTRATIVE EXAMPLES OF MODES AND TIMING OF DATA COLLECTION

\begin{tabular}{|l|l|l|}
\hline \multicolumn{2}{|c|}{ CHWs } & \multicolumn{1}{c|}{$\begin{array}{c}\text { Clients/ } \\
\text { community } \\
\text { members }\end{array}$} \\
\hline $\begin{array}{l}\text { Brief set of } \\
\text { indicators }\end{array}$ & $\begin{array}{l}\text { SPAs, every 6-12 } \\
\text { months }\end{array}$ & $\begin{array}{l}\text { Community } \\
\text { scorecards, every } \\
\text { 6-12 months }\end{array}$ \\
\hline $\begin{array}{l}\text { Full set of } \\
\text { indicators }\end{array}$ & $\begin{array}{l}\text { Special studies, } \\
\text { every 2-3 years }\end{array}$ & $\begin{array}{l}\text { Special studies, } \\
\text { DHS into }\end{array}$ \\
\hline
\end{tabular}

Consider collecting qualitative data with $\mathrm{CHWs}$ and community members/clients, to complement quantitative data from indicators. This may be especially helpful in interpreting data from indicators used for the first time. Longer-term, qualitative data collection could help explain trends in indicators observed over time.

Share your experiences implementing the indicators. Lessons learned can be periodically reviewed by global stakeholders for continuous quality improvement.

Suggested citation: Frontline Health Project. 2021. Operationalized Indicators: Integrating Community Health Worker and Client Views to Assess Community Health Systems. Washington, D.C.: Population Council.

\section{CONTACT}

Pooja Sripad

Population Council

Washington, D.C.

psripad@popcouncil.org

Ann Gottert

Population Council

Washington, D.C.

agottert@popcouncil.org
Tracy McClair

Population Council

Washington, D.C.

tmmclair@popcouncil.org

Charlotte Warren

Population Council

Washington, D.C.

cwarren@popcouncil.org 


\section{REFERENCES}

1. Perry HB, Zulliger R, Rogers MM. Community health workers in low-, middle-, and high-income countries: an overview of their history, recent evolution, and current effectiveness. Annu Rev Public Heal. 2014;35:399-421.

2. World Health Organization. 2018. WHO guideline on health policy and system support to optimize community health worker programmes. Available from: http://apps.who.int/iris/bitstream/handle/10665/275474/9789241550369-eng.pdf

3. Kok MC, Dieleman M, Taegtmeyer M, Broerse JEW, Kane SS, Ormel H, et al. Which intervention design factors influence performance of community health workers in low- and middle-income countries? A systematic review. Health Policy Plan. 2015;30(9):1207-27.

4. Indicator Guide: Monitoring and evaluating integrated community case management. 2013. Available from: http://1rqxbs47ujl4rdy6q3nzf554. wpengine.netdna-cdn.com/wp-content/uploads/2016/07/iCCM-Indicator-Guide.pdf

5. World Health Organization. 2021. CHW Monitoring \& Accountability template. Available from: http://apps.who.int/iris/bitstream/hand le/10665/275474/9789241550369-eng.pdf

6. Agarwal S, Sripad P, Johnson C, Kirk K, Bellows B, Ana J, et al. A conceptual framework for measuring community health workforce performance within primary health care systems. Human resources for health, 2019;17(1), 86.

7. UNICEF, World Health Organization, Global Fund to Fight AIDS, Tuberculosis and Malaria, United Nations Entity for Gender Equality and the Empowerment of Women, and Gavi, the Vaccine Alliance. 2021. Guidance for community health worker strategic information and service monitoring. Available from: https://www.healthdatacollaborative.org/fileadmin/uploads/hdc/Documents/Working_Groups/Community_ Data/210305_UNICEF_CHW_Guidance_EN.pdf

8. UNICEF. Minimum Quality Standards and Indicators for Community Engagement. 2020. Available from: https://www.unicef.org/mena/ media/8401/file/19218_MinimumQuality-Report_v07_RC_002.pdf.pdf

9. Advancing Partners \& Communities. 2018. Community Scorecard Toolkit: Empowering Communities and Healthcare Providers to Partner in Leading Change. Available from: https://www.advancingpartners.org/sites/default/files/sites/default/files/resources/tagged_apc_lci_ community_scorecard_toolkit.pdf

10. Frontline Health Project. 2020. Frontline Health: Harmonizing Metrics, Advancing Evidence, Accelerating Policy Project Overview Brief. Washington, D.C.: Population Council. Available from: https://www.popcouncil.org/uploads/pdfs/2020RH_FrontlineHealthOverviewBrief.pdf

11. Community Health Impact Coalition, Initiative Inc., UNICEF, USAID. 2018. Community Health Worker Assessment and Improvement Matrix (CHW AIM): Updated Program Functionality Matrix for Optimizing Community Health Programs. Available from: https://chwcentral.org/wp-content/ uploads/2018/12/CHW-AIM-Updated-Program-Functionality-Matrix_Dec-2018-005.pdf

12. Chen N, Raghavan M, Albert J, et al. The community health systems reform cycle: strengthening the integration of community health worker programs through an institutional reform perspective. Glob Health Sci Pract. 2021;9(Suppl 1). doi:10.9745/GHSP-D-20-00429

13. USAID, UNICEF. Community Health Roadmap: Investment priorities to scale primary care at the community level. Available from: https://www. communityhealthroadmap.org/

14. Morrow M, Sarriot E, Nelson AR, et al. Applying the community health worker coverage and capacity tool for time-use modeling for program planning in Rwanda and Zanzibar. Glob Health Sci Pract. 2021;9(Suppl 1). doi:10.9745/GHSP-D-20-00324

15. Frontline Health Project. November 2020. Scales to Measure Motivation among Community Health Workers, and Trust and Empowerment among their Clients: A Guide. Washington, DC: Population Council. Available from: https://www.popcouncil.org/uploads/pdfs/2020RH_ FrontlineHealthScalesGuide.pdf

16. Gottert A, McClair TL, Hossain S, Dakouo SP, Abuya T, Kirk K, Bellows B, Agarwal, S, Kennedy S, Warren C, Sripad P. Development and validation of a multi-dimensional scale to assess community health worker motivation. J Glob Health 2021,11:07008

17. Frontline Health Project. November 2020. Scales to Measure Motivation among Community Health Workers , and Trust and Empowerment among their Clients: A Guide. Washington, D.C.: Population Council.

18. McClair TL, Sripad P, Casseus A, Hossain S, Abuya T, Gottert A. The Client Empowerment in Community Health Systems Scale: Development and validation ithree countries. J Glob Health 2021;11:07010.

19. Sripad P, McClair TL, Causseus A, Hossain S, Abuya, Gottert A. Measuring client trust in community health workers: A multi-country validation study. J Glob Health 2021;11:07009 